\title{
Scape, Rhizome and Root Anatomy of Polygonatum Species from Turkey
}

\author{
Yeter Yesil' ${ }^{10}$, Fatma Neriman Ozhatay² \\ IIstanbul University, Faculty of Pharmacy, Istanbul, Turkey \\ 2Eastern Mediterranean University, Faculty of Pharmacy, Gazimağusa, North Cyprus, Turkey
}

ORCID IDs of the authors: Y.Y. 0000-0002-4458-7881; F.N.0. 0000-0003-4062-7492

Please cite this article as: Yesil Y, Ozhatay FN. Scape, Rhizome and Root Anatomy of Polygonatum Species from Turkey. Eur J Biol 2021; 80(2): 164-172. DOI: 10.26650/EurJBiol.2021.1026981

\section{ABSTRACT}

Objective: Polygonatum (Asparagaceae) is a rhizomatous monocotyledon genus that is distributed in the temperate regions of the Northern Hemisphere. The genus is represented by 5 species in Turkey ( $P$. glaberrimum, P. latifolium, P. multiflorum, $P$. verticillatum and $P$. orientale). Karyological, palynological, phylogenic, chemotaxonomical and some anatomical studies of Polygonatum species have been carried out previously. However, the detailed anatomical features of the scape, rhizome and root of Polygonatum species grown in Turkey have not been examined before and so the aim of this study is to determine their anatomical characteristics. Also, the study compares the species with each other according to obtained anatomical characteristics and comparing them with previous anatomical studies.

Materials and Methods: Investigations were carried out on fresh material collected from wild habitats during July 20092012 in Turkey. Cross-sections of scape, rhizome and roots were cut by hand, detailed photographs were taken under a light microscope, and anatomical structures were drawn in detail with an isograph pen.

Results: The anatomical structures of Polygonatum species have monocotyledones features. Significant differences between species were observed, such as the number of costas in the scape, number of xylem arms in the root and the types of vascular bundle in the rhizome. Also, the anatomical characteristics of the species were compared with previous anatomical studies.

Conclusion: The anatomical features determined by this study will be useful at the species level as well as at the genus and family level. Hence the obtained data will contribute to the literature.

Keywords: Polygonatum, Asparagaceae, Anatomy, Solomans seal, Turkey

\section{INTRODUCTION}

Polygonatum Miller. species grow in warm temperate regions in the boreal zones of the northern hemisphere and are represented by a total of 71 species and 4 varieties (1-3) across the world and by 5 species in Turkey (4). Polygonatum is a rhizomatous herb and the biggest genus of the family Asparagaceae. Early on it was classified as a member of the Liliaceae family (or in some countries the Convallariaceae family) and was later classified into the Asparagaceae family (5-7).

The genus Polygonatum is seperated into tree sections according to leaf sequences, size of perianth, whether bracts are present or not and the chromosome bases number; sect. Polygonatum, sect. Oppocitifolia and sect. Verticillata (8-12). Also, sect. Verticillata has shouting stamen filaments, perforated pollen exines, and most of the pollen has opposite or vertical leaves with slender type filaments (13).

Tamura (14) subdivided the genus into two sections, sect. Polygonatum (Alternifolia) and sect. Verticillata Baker., Sect. Polygonatum possesses alternate leaves, stout staminal filaments, perforated pollen exines, $x=9,10$ or 11 as chromosome base number. Sect. Verticillata has mostly opposite or verticillate leaves, 
slender filaments, mostly reticulate pollen exines, $x=14$ or 15 as base chromosome number $(14,15)$. Also, Tamura (14) divided sect. Polygonatum into three series, ser. Bracteata L. Abramova, ser. Polygonatum and ser. Inflata (Satake) M. N. Tamura based on the karyological and micromorphological characters of the staminal filaments.

The phylogenetic studies (16) have primarily focused on relationships at the tribal level. Meng and friends (13) studied the phylogenetic analysis of the Polygonatum species using data from two plastid coding regions, rbcL and trnK (matK), and two non-coding regions, $p s b A-t r n H$ and $\operatorname{trnC}$-petN. They also, tested the monophyly of Polygonatum, reconstruct phylogenetic relationships and examined the character evolution of phyllotaxis in the genus. Moreover, a recent phylogenetic study provided support for the recognition of Polygonatum, Disporopsis and Heteropolygonatum within Polygonatum genus (17).

The leaf anatomy of Polygonatum species grown in China was studied and it was noted that leaf thickness, the appearance of raffite or other crystals and size of stoma are significant features. Also, it has been noted that there is no sponge and palisade parenchyma differentiation in the mesophyll tissue (18-22). Foliar epidermal characteristics, such as, thickness of cell wall, different types of stomata, and epidermis of the Polygonatum species have been used for the classification of the Asparagaceae taxa $(23,24)$, additionally the micromorphological characteristics of the epidermis of six species of the Polygonatum have been studied from different geographic populations of China (25). The anatomical structure of Polygonatum Mill. species in the Precarpathian region were studied recently (26), although the Polygonatum species is mentioned in the article, only the features of $P$. multiflorum are shown with photographs.

Also, the used parts of two medicinal Polygonatum species ( $P$. verticillatum and $P$. cirrhifolium) were studied, but mostly the pharmacognostic properties of the species were indicated in this study (27).

Kauff and friends (28) studied the root anatomy of several taxa of Asparagales and certain taxa formerly included in Asparagales described in a systematic context together with a literature review. However, there is no detailed systematic study on root, scape and rhizome anatomy of Polygonatum species. This study aimed to investigate the scape, rhizome and root anatomical features of Polygonatum species grown in Turkey.

\section{MATERIALS AND METHODS}

The study materials were collected during the doctoral dissertation study 'Pharmaceutic Botanical Investigation on Polygonatum Mill., Paris L., Veratrum L. genera in Turkey'. The studied Polygonatum samples were gathered from different regions of Turkey during July 2010 and July 2012. The herbarium numbers, locations and collection dates of the samples are given in Table 1. The Latin name of species were verified by Kew's vascular plant database (3), Flora of Turkey (29), the Illustrated Flora of Turkey database (30) and the Turkey Plant list (Vascular Plants) (31). The voucher specimens were kept in the herbarium of Istanbul University Faculty of Pharmacy (ISTE). The collected specimens for anatomical study were stored in $70 \%$ ethyl alcohol in the field trips.

The transverse sections of the Polygonatum species were cut by hand, the samples were investigated in Sartur reagent (a compound reagent of Sudan III, lactic acid, iodine, aniline, alcohol, potassium iodide and water) (32). Photographs were taken with the Canon Power shot A640.

The cross-sections of the rhizome were taken from the knuckle of the scapular and the knee of the previous year. The cross sections of the root were taken from the root of the scapulae and the roots of the previous year's stranglehold. Observations were made with a $\mathrm{BH} 2$ Olympus Light Microscope-Philips camera and a Leica DFC 295 stereo microscope.

The anatomical investigations referred to were: "Applied Plant Anatomy" (33), "Plant Anatomy Part 1-2" (34,35), "Anatomy of Flowering Plant" (36) and "Bitki Anatomisi" (37).

\section{RESULTS}

The scape, rhizome and root anatomy of the Polygonatum species were documented and represented in Figures.

Table 1. The list of studied species and some label information.

\begin{tabular}{llll}
\hline Species & $\begin{array}{l}\text { Herbarium } \\
\text { Number }\end{array}$ & Locations & Collection date \\
\hline Polygonatum glaberrimum & ISTE 97684 & Ardahan: Çıldır, $1405 \mathrm{~m}$. & 06 vii 2011 \\
\hline Polygonatum latifolium & ISTE 97530 & Kırklareli: Dereköy, $454 \mathrm{~m}$. & 10 v 2011 \\
\hline Polygonatum multiflorum & ISTE 97507 & Artvin: Borçka, $426 \mathrm{~m}$. & 08 viii 2010 \\
\hline Polygonatum orientale & ISTE 97464 & Kastamonu: Taşköprü, $1183 \mathrm{~m}$ & 28 vii 2010 \\
\hline Polygonatum verticillatum & ISTE 97486 & Trabzon: Maçka, $1534 \mathrm{~m}$. & 28 iii 2010 \\
\hline
\end{tabular}




\section{Scape Anatomy}

The scape of the Polygonatum species show anatomical characteristics of the stem (Figures 1-3).

Epidermis, epidermis cells are single layered, isodiametric and have a thick cell wall. The cuticle is thick and stomata are present. Papilla and small trichomes are present in P. verticillatum. 2-4 small trichomes or 1-2 (-3) scabride trichomes are present on costas and papilla and small trichome and stomata are present in between the costas of $P$. orientale. In the costas of $P$. latifolium there is unicellular trichome. $P$. glaberrimum does not have trichomes (Figures 1A, 2A and 2B).

Cortex, P. multiflorum does not have costas and has 2 or 3 layers of lignifiedcells under the epidermis. Parenchymatous tissue is 2 or 3 layered cells, in a rounded or polygonal shape and very big. The species which have costas, have 2-5 layers of collenchymatous tissues under the epidermis cells (Figures 1 and 2).

Central cylinder, vascular bundles, and the tissue in which they are contained are surrounded by 3-6 layers of sclerenchymatous tissue. Vascular bundles are small in the sclerenchyma ring, but central vascular bundles are larger and rarely have sclerenchymatous tissues. Also, the surrounded phloem are in the form of a $U$ or $V$ shape in central vascular bundles xylem. Pith is unspecified or parenchymatous (Figure 2).

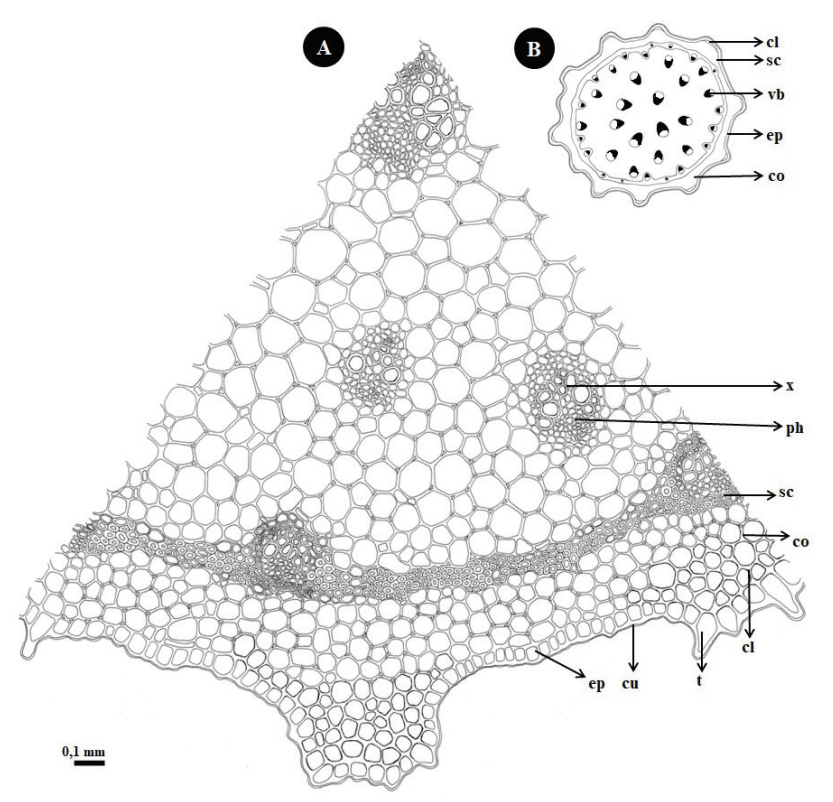

Figure 1. The illustrations of scape cross section of Polgonatum orientale (ISTE 97464); (A) detailed illustration, (B) schematic illustration, cl: collenchyma, co: cortex, cu: cuticule, ep: epidermis, ph: phloem, sc: sclerenchyma, t: trichome, vb: vascular bundle, $x$ : xylem.
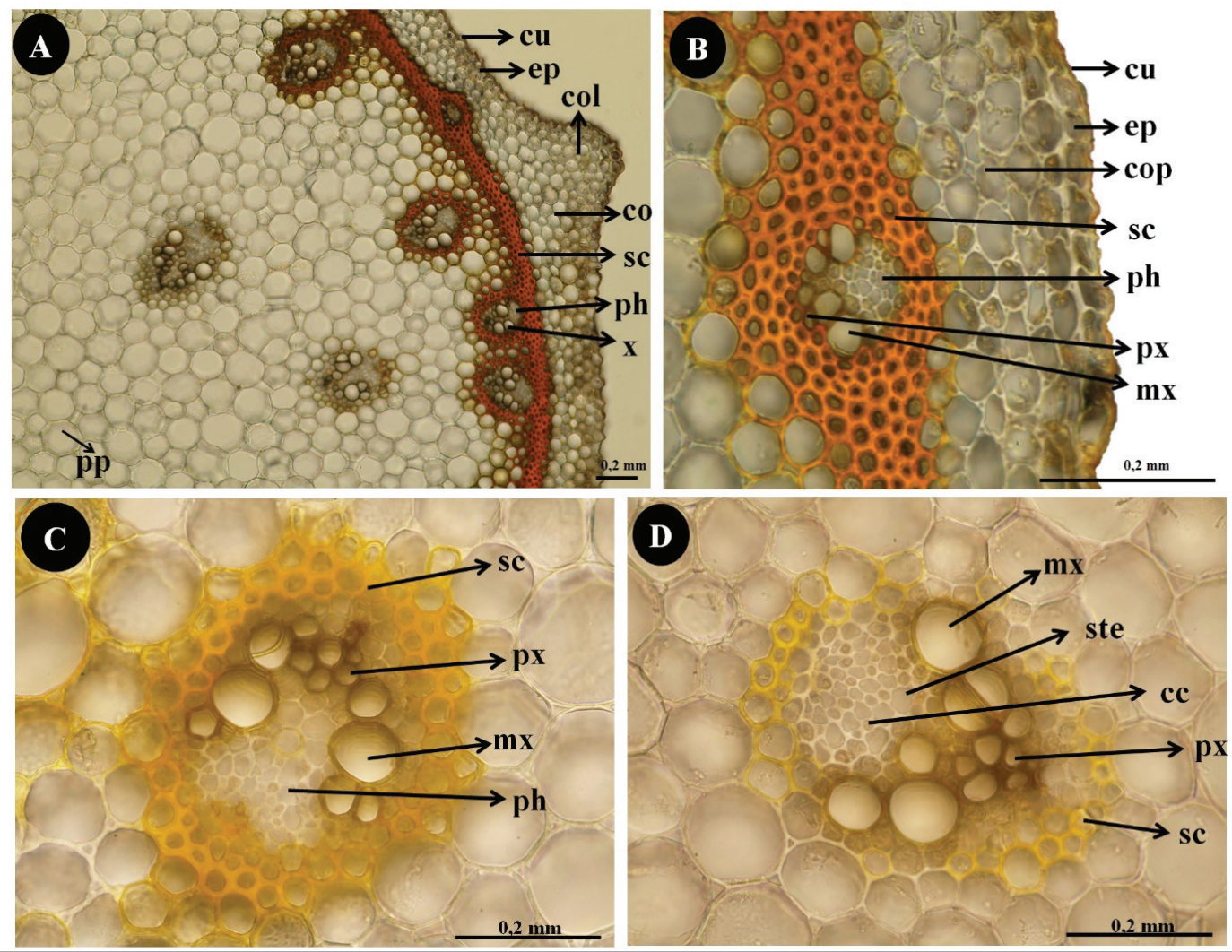

Figure 2. Cross section of scape of Polygonatum glaberrimum; (A) general view, (B) cortex and vascular bundle, (C) marginal vascular bundle, (D) central vascular bundle, cc: companion cell, co: cortex, col: collenchyma, cop: cortex parenchyma, cu: cuticule, ep: epidermis, mx: metaxylem, ph: phloem, px: protoxylem, sc: sclerenchyma, ste: sieve tube element, $x$ : $x y l e m$. 


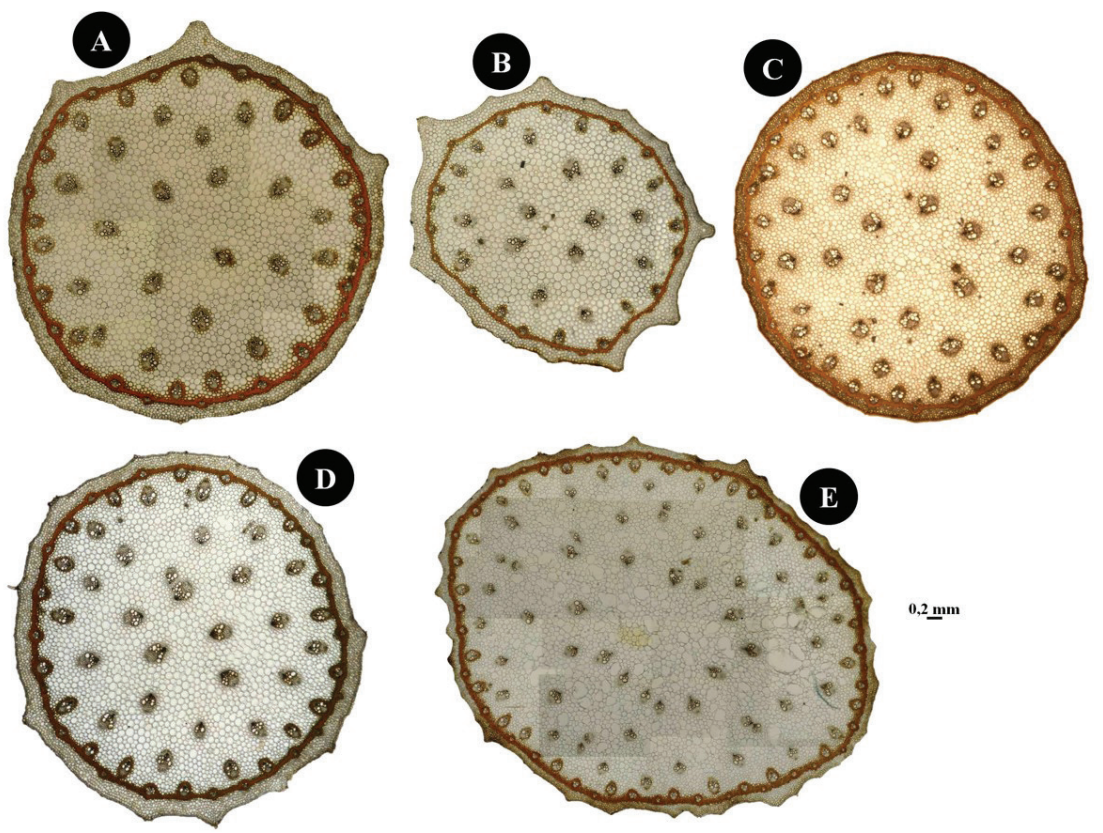

Figure 3. Cross section of scapes of the speceis; (A) Polygonatum glaberrimum, (B) Polygonatum latifolium, (C) Polygonatum multiflorum, (D) Polygonatum orientale, (E) Polygonatum verticillatum..

Although scape anatomy has the characteristics of a monocotyledon stem anatomy, the sclerenchyma tissue formed a circle under the cortex as in a dicotyledon stem. Some vascular bundles are also located at a distance in this tissue. Other vascular bundles are irregular in the central cylinder. Central vascular bundles are larger and less numerous than those close to the cortex. Therefore, the scape shows typical monocotyledonous stem anatomy. The bundles are collateral (Figures 1, 2A, and 3).

In addition, the presence of costas in the scapes of Polygonatum species and, if any, the size of the costas differ according to the species. P. glaberrium and P. latifolium species have big costas, $P$. verticillatum and $P$. orientale species have smaller costas, $P$. multiflorum species do not have costas. In the central cylinder, bands of raphide are rarely seen. Detailed examination results are given below (Figure 3).

\section{Rhizome Anatomy}

The rhizomes of the Polygonatum species show characteristics of monocotyledones rhizome anatomy. Raphides and starch grains are present.

Epidermis cells are single layered, rectangular and have a thick cell wall. The cuticle is very thick (Figures $4 A$ and $5 B$ ).

Cortex, there are thick-walled, different-sized, polygonal, oval or round parenchymal cells located here. Since there was no endodermis, there was no definite boundary between the cortex and the central cylinder (Figures 4 and 5).

Central cylinder, under the cortex, the vascular bundles are arranged in a circle (Figures 4B and 5A). Some xylem and phlo-

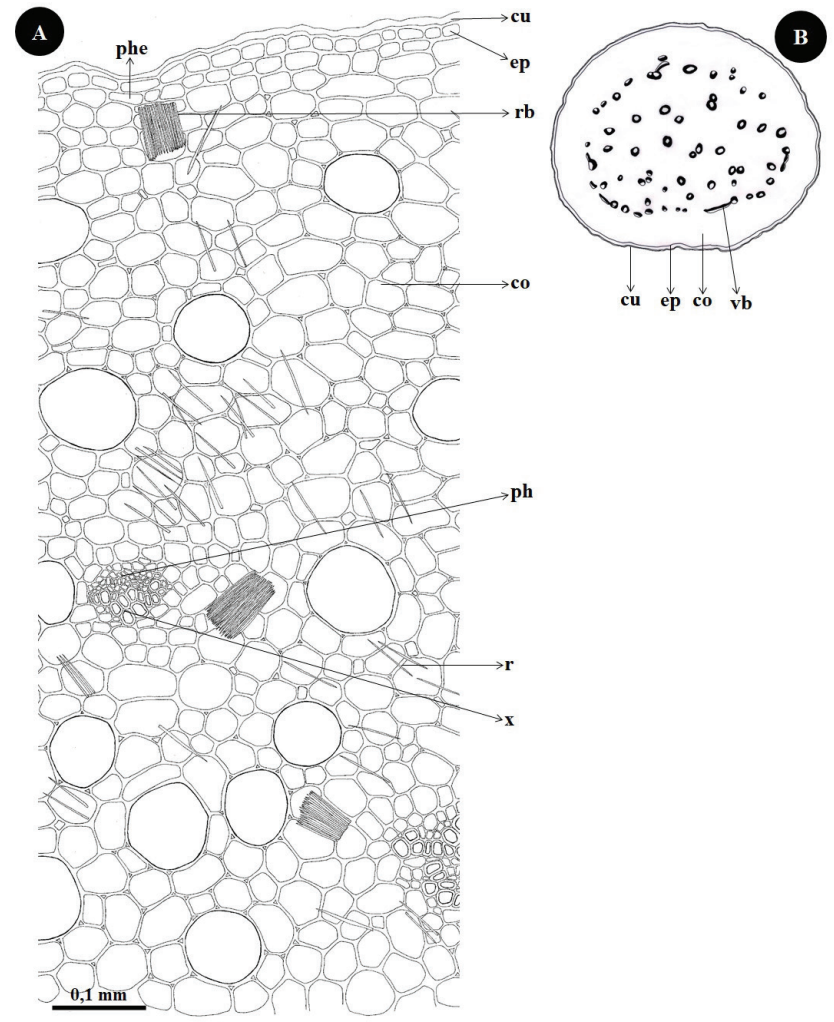

Figure 4. The illustrations of rhizome cross section of Polgonatum orientale (ISTE 97464); (A) detailed illustration, (B) schematic illustration, co: coteks, cu: cuticule, ep: epidermis, ph: phloem, phe: phellogen, $r$ : raphide, rb: raphide bundle, vb: vascular bundle, $x$ : xylem. 

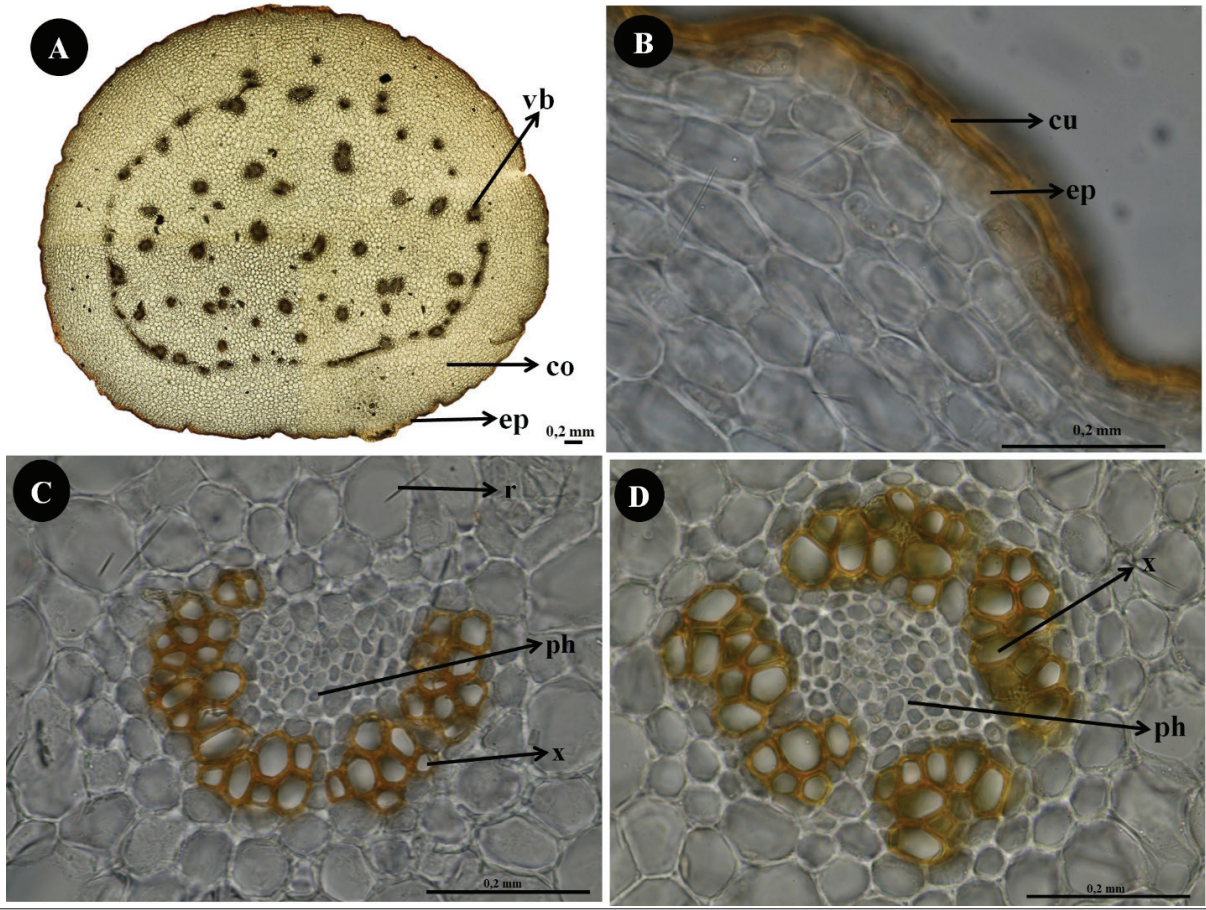

Figure 5. The rhizome cross section of Polygonatum orentale (ISTE 97464); (A) general view of rhisome, (B) cortex and epidermis, (C) central vascular bundle with $U$ shaped xylem, (D) central vascular bundle with amfivasal xylem, co: coteks, cu: cuticule, ep: epidermis, ph: phloem, r: raphide, vb: vascular bundle, $x$ : xylem.

em of vascular bundles in the circle are united at long distance. These vascular bundles and close vascular bundles are collateral. But the vascular bundles which are bigger and diffused near the center are amfivasal or the phloem is surrounded by xylem $U$ shaped and particularly amfivasal vascular bundles surrounded by a single layered bundle-sheath (Figures 4B, 5C and 5D). The cell walls of xylem are reticulat. Pith is unspecified, parenchymatous (Figure 4A).

\section{Root anatomy}

The roots of Polygonatum species do not show characteristics of monocotyledones root anatomy. Raphide crystals are present (Figures 6-8).

Epidermis is replaced by the spongy tissue, the velamen. Velamen is single layered (Figures 6B and 7A).

Cortex has different cells in size and shapes. Endodermis is one layered with 1-3 transition cells, endodermis cells with thickened radial and inner tangential walls (Figures 6B, 7A, 7B and 8).

Central cylinder, pericycle cells are single layered, thin-walled, in different sizes and shapes. Vascular bundles are radial and xylem has 4-9 arm, metaxylem and protoxylem, metaxylem vessels thick walled thickenings on lateral walls of vessels scalariform perforation plates, of vessels simple or scalariform. Phloem has polygonal small thin-walled cells. Pith is sclerenchymatous (Figures 6B, 7 and 8).

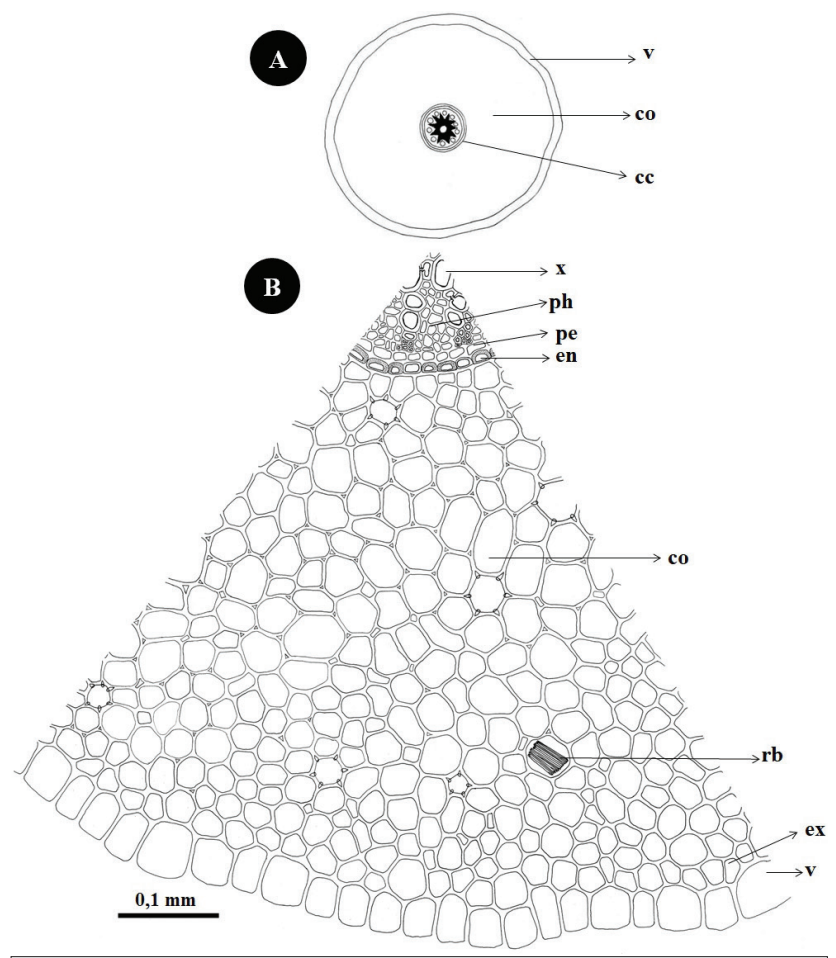

Figure 6. The illustrations of root cross section of Polgonatum orientale (ISTE 97464); (A) schematic illustration, (B) detailed illustration, cc: central cylinder, co: cortex, ex exodermis, en: endodermis, pe: pericycle, ph: phloem, rb: raphide bundle, $x$ : xylem, v: velamen. 

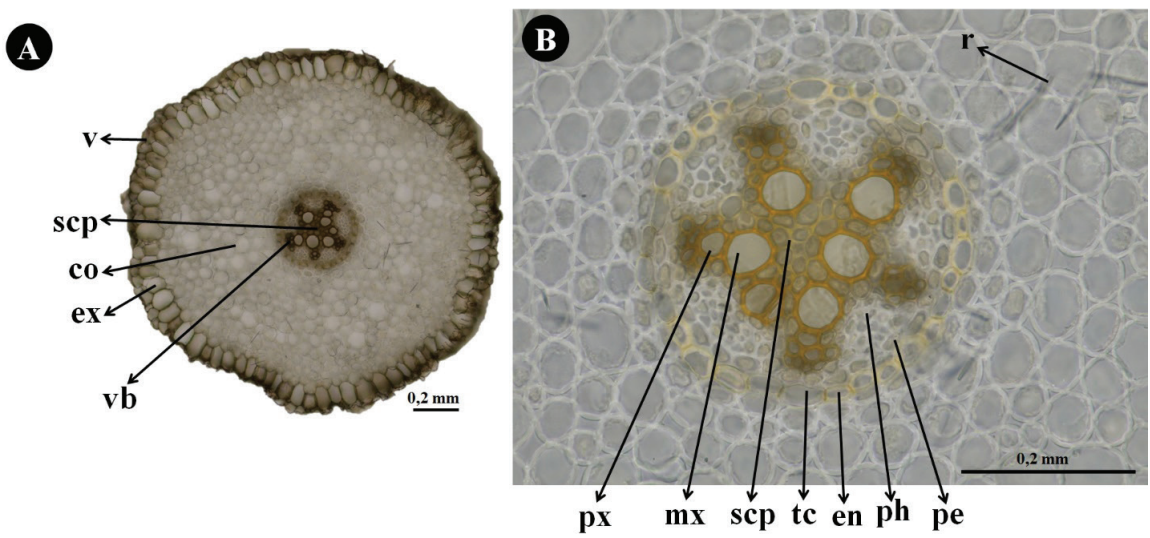

Figure 7. The root cross section of Polygonatum latifolium (ISTE 97530); (A) general view of root, (B) the central cylinder, co: cortex, ex: exodermis, en: endodermis, mx: metaxylem, pe: pericycle, ph: phloem, px: protoxylem, tc: transition cell, scp: sclerenchymatious pith, $\mathrm{x}$ : xylem, v: velamen.
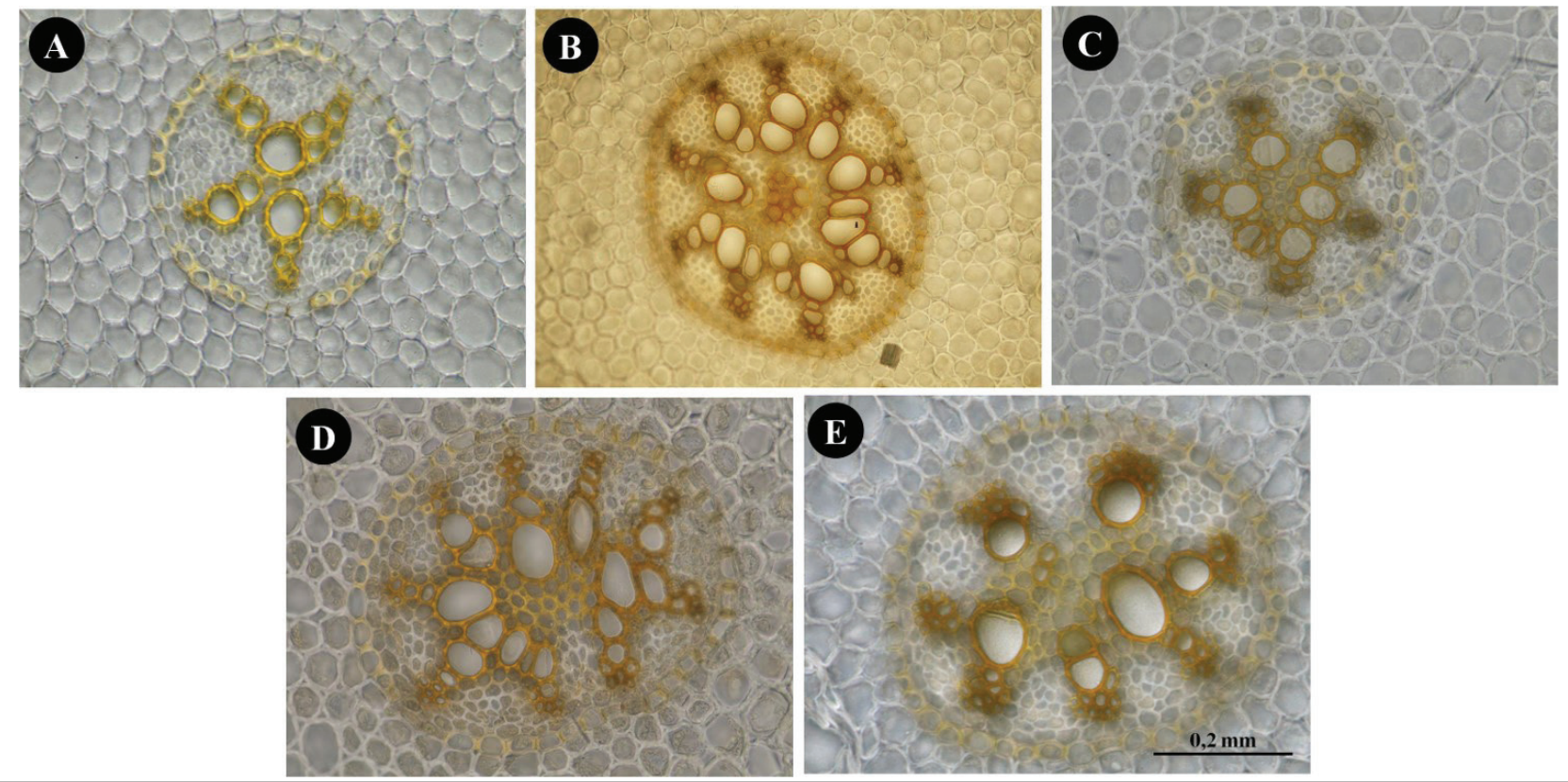

Figure 8. The cross section of root central cylinder of the species; (A) Polygonatum glaberrimum, (B) Polygonatum orientale, (C) Polygonatum latifolium, (D) Polygonatum multiflorum, (E) Polygonatum verticillatum.

\section{DISCUSSION}

This study covers the scape, rhizome and root anatomical features of Polygonatum species distributed in Turkey. The samples of 5 species, collected from different regions of Turkey, were studied in detail. An anatomical key was created in light of obtained data and important anatomical features of the studied species can be seen in Table 2.

There is a marked difference in the size of costas between Polygonatum species in scape anatomy. Costas are few in number but large in P. glaberrium and P. latifolium species, for this reason, the cortex of these species are larger. Costas are many and small in $P$. verticillatum and $P$. orientale, no costa was observed in $P$. multiflorum species. Therefore, collenchyma tissue is denser in species with large costa compared to species with small costa. Also, the cortex consists of more parenchymatous layers.

When the study researching the anatomical structures of the scapes and phylloclades of Bulgarian Ruscus species were investigated (38), the similarities of Polygonatum and Ruscus species in scape anatomy were easily observed. These similarities were the presence of costas, a single layer of the epidermis, a well-developed sclerenchyma ring, and the distribution of vascular bundles in central cylinder and type of vascular bundles. 
Table 2. Scape, rhizome and root characteristics of Polygonatum species.

\begin{tabular}{|c|c|c|c|c|c|}
\hline Characteristics & P. glaberrimum & P. Iatifolium & P. multiflorum & P. orientale & P. verticillatum \\
\hline Number of costas in scapes & $3-4$ & $6-7$ & - & $10-17$ & $25-35$ \\
\hline Collenchyma layers in scapes & $4-5$ & $2-4$ & - & $2-3$ & $1-3$ \\
\hline Xylem arms in roots & $4-5$ & $5-7$ & $5-10$ & $5-9$ & $5-7$ \\
\hline Starch grain in rhizomes & + & + & + & + & ++ \\
\hline $\begin{array}{l}\text { Types of vascular bundles in } \\
\text { rhizomes }\end{array}$ & $\begin{array}{l}\text { Collateral or } \\
\text { concentric- } \\
\text { amphivasal type }\end{array}$ & Collateral type & $\begin{array}{l}\text { Collateral or } \\
\text { concentric- } \\
\text { amphivasal type }\end{array}$ & $\begin{array}{l}\text { Collateral or } \\
\text { concentric- } \\
\text { amphivasal type }\end{array}$ & $\begin{array}{l}\text { Collateral or } \\
\text { concentric- } \\
\text { amphivasal type }\end{array}$ \\
\hline
\end{tabular}

Although these two genera are not completely similar in morphology, the reason for their anatomical similarity may be that they are in the same family (Asparagaceae).

Study of the rhizome revealed characteristics of monocotyledones stem. The rhizome of $P$. verticillatum contains more starch grains than the rhizome of other species. All species contain a large number of raphide bundles. Vascular bundles are collateral or concentric-amphivasal type. Only the P. latifolium species does not have amphivasal type vascular bundles.

The root generally has monocotyledones properties in Polygonatum species. Endodermis are seen as horseshoe, but not very distinct when compared to other monocotyledones. Polygonatum species have different numbers of xylem arms in the central cylinder, in particular $P$. multiflorum, $P$. orientale and $P$. verticillatum species, where as many as 10 were detected.

This study supports the study of Kauf and friends (27) because of the presence of raphide crystals, endodermis cells with thickened radial and internal tangential walls and the presence of sclerenchymatous tissue in the central pith of root. The epidermis layer can often be replaced by the velamen layer or layers in the root. The species with velamentous roots are geophytes and hemicryptophytes that grow in zones with a dry tropical climate or Mediterranean climates. Velamen tissue protects the root tissue and prevents water loss (39). The velamen tissue of Polygonatum species growing in Turkey is one layered. Because these species are not distributed in very dry areas, their habitats are mixed forests or mixed needle-leaved forests.

The roots of Polygonatum and Sansevieria are very similar, but while vascular bundles are absent in the central pith of Polygonatum, collateral bundles and vascular bundles are present in the central pith in roots of Sansevieria (40).

The types of calcium oxalate crystals were stated as differing by species in a previous study (41). However, no difference in the types of calcium oxalate crystals was observed between the species in this study.

The rhizome and root anatomical features of Polygonatum verticillatum have some overlaps with the Pandey and friends study (27). However, in contrast to the study, the periscle was easily observed in the root anatomy of Turkish $P$. veriticillatum species, in addition the endoderma is indistinct in the rhizome, the vascular bundles are particularly amphivasal and they are surrounded by a single layered bundle-sheath.

It has been stated that the difference in the shapes of endodermal cells in the leaves of Polygonatum species may be due to temperature and geographical distribution (42). Similarly, In the current study, whether the scapuses of Polygonatum species had costas or not, the number or the size of the costs can be explained by temperature and geographical variation.

Tamura (14) divided Polygonatum species into two groups - the Alternifolia group and the Verticillata group - in his classification based on chromosome numbers and filament surface properties. Another study based on numbers of chromosomes, karyological structures and karyotypic constitution also confirmed these results (2). When we evaluated the anatomical features in this study in this scope, although there were differences between $P$. verticillatum, which is a verticillate leaved species, and other species with alternate leaves, there was no significant grouping in these species.

\section{Key for anatomical determination of the investigated spe- cies}

1. Costas and collenchyma layers absent in scape P. multiflorum

1. Costas and collenchyma layers present in scape ............2

2. Numbers of costas more than 20 , collenchyma layers $1-3 \ldots$ .............. verticillatum

2. Numbers of costas less than 20, collenchyma layers more than $1-3 \ldots . . .3$

3. Numbers of costas at least 9 . P. orientale

3. Numbers of costas maximum $7 \ldots \ldots \ldots \ldots \ldots \ldots \ldots \ldots \ldots \ldots$

4. Vascular bundle only collateral in rhizome, xylem arms $\geq 5$. ..P. latifolium

4. Vascular bundle collateral or concentric-amphivasal in rhizome, xylem arms $\leq 5 \ldots \ldots \ldots$. P. glaberrimum 


\section{CONCLUSION}

Polygonatum species can be confused with each other when analysed morphologically, especially $P$. orientale and $P$. multiflorum or $P$. multiflorum and $P$. glaberrimum species if they don't have parts such as flowers or fruit. However, the obtained anatomical characteristics such as the size of the costas show noticeable differences for distinguishing the species. Therefore, the anatomical characteristics of these species play an important role which may be the reference to use as an additional tool for the correct identification.

The anatomical features determined by this study may be useful at the genus level as well as at the species level. Thus, the data obtained in this study may lead to different studies to be conducted on both the Polygonatum genus and the genera in the Asparagaceae family.

Acknowledgement: We would like to thank Prof. Dr. Emine Akalın for her valuable suggestions during the writing process of the doctoral thesis.

Informed Consent: Written consent was obtained from the participants.

Peer Review: Externally peer-reviewed.

Author Contributions: Conception/Design of Study- Y.Y., N.O.; Data Acquisition- Y.Y.; Data Analysis/Interpretation- Y.Y.; Drafting Manuscript- Y.Y., N.O.; Critical Revision of Manuscript- Y.Y.; Final Approval and Accountability- Y.Y., N.O.

Conflict of Interest: Authors declared no conflict of interest.

Financial Disclosure: This study was supported by the Scientific Research Projects Unit of Istanbul University within the scope of the thesis project numbered 5923.

\section{REFERENCES}

1. Chien-Ti C, Yen-Hsueh T. Revision of Polygonatum (Asparagaceae, Nolinoideae, Polygonateae) of Taiwan. PhytoKeys 2019; 117: 99-118.

2. Deng XY, Wang Q, He XJ. Karyotypes of 16 populations of eight species in the genus Polygonatum (Asparagaceae) from China. Bot J Linn Soc 2009; 159(2): 245-54.

3. The Plant List, 2021. 〈http://www.theplantlist.org/〉. (Accessed 20 September 2021).

4. Yeşil Y. Polygonatum, Paris ve Vertarum cinsleri üzerinde farmasötik botanik çalışmalar. I..ü. Sağlık Bilimleri Enstitüsü, Doktora Tezi. 2013.

5. Byng JW, Chase MW, Christenhusz MJM, Fay MF, Judd WS, Mabberley $D$, et al. An update of the Angiosperm Phylogeny Group classification for the orders and families of flowering plants: APG IV, Bot J Linn Soc 2016; 181(1): 1-20.

6. Reveal JL, Chase MW. Bibliographical Information and Synonymy of Magnoliidae: APG III. Phytotaxa 2011; 19: 71-134.

7. Seberg O, Petersen G, Davis Jl, Pires CP, Stevenson DW, Chase MW, et al. Phylogeny of the Asparagales based on three plastids and two mitochondrial genes. Am J Bot 2012; 99: 875-89.

8. Abramova LI. On the taxonomical structure of the genus Polygonatum Mill. Botaniceskii Žurnal 1965; 60: 490-7.
9. Baker JG. Revision of the genera and species of Asparagaceae. J Proc Linn Soc Bot 1875; 14: 508-46.

10. Chang GJ, Kim YS. Morphological evolution and relationships of Korean Polygonatum. Korean J PIt Taxon 1999; 29: 135-49.

11. Jeffrey C. The genus Polygonatum in eastern Asia. Kew Bull 1980; 34: 435-71.

12. Tamura MN. Biosystematic studies on the genus Polygonatum (Liliaceae) I. Karyotype analysis of species indigenous to Japan and its adjacent regions. Cytologia 1990; 55: 443-66.

13. Meng Y, Nie ZL, Deng T, Wen J, Yang YP. Phylogenetics and evolution of phyllotaxy in the Solomon's seal genus Polygonatum (Asparagaceae: Polygonateae). Bot J Linn Soc 2014; 176(4): 435-51.

14. Tamura MN. Biosystematic studies on the genus Polygonatum (Liliaceae) III. Morphology of staminal filaments and karyology of eleven Eurasian species. Bot Jahrb Syst 1993; 115: 1-26.

15. Tamura MN. Taxonomic studies on the genus Polygonatum (Liliaceae). Proc Jpn Soc PI Taxon 1993; 9: 73-81.

16. Tamura MN, Schwarzbach AE, Kruse S, Reski R. Biosystematic studies on the genus Polygonatum (Convallariaceae) IV: Molecular phylogenetic analysis based on restriction site mapping of the chloroplast gene trnK. Feddes Repert 1997; 108: 159-68.

17. Floden A, Schilling EE. Using phylogenomics to reconstruct phylogenetic relationships within tribe Polygonateae (Asparagaceae), with a special focus on Polygonatum. Mol Phylogenet Evol 2018; 129: 202-13.

18. Chen CW, Li YT, Zhou SB. Comparative investigation on leaf epidermis of five species of Polygonatum from Dabieshan. J Anhui Agric Univ 2006; 33(1): 108-12.

19. $\mathrm{Li}, \mathrm{JH}$, Zhou SB, Wang CJ, Yu BQ. Comparative Anatomy of the Leaves in Polygonatum from Anhui Province. Acta Bot Yunnan 2005; 27(5): 509-16.

20. Li, JH, Zhou SB, Wang Y, Tian, CC. Leaf comparative anatomy of Polygonatum cyrtonema from five populations. Guihaia 2007; 27(6): 826-31.

21. Meng Y, Wang JJ, Nie ZL. Comparative morphology of leaf epidermis in 34 species of Maianthemum (Asparagaceae, Polygonateae) and their systematic significance. Phytotaxa 2016; 275(2): 81-96.

22. Zheng Y, Wang Y, Zhou H-B, Xu RS, Lian S, Zhang DC. Study on the leaf epidermis of Polygonatum from Anhui Province. Guihaia 1999; 19: 263-6.

23. Çitak BY, Dural H, Uysal T. Comparative anatomical and morphological studies on six Muscari species (Asparagaceae). Biol Divers Conserv 2019; 12(2): 141-50.

24. Raycheva T, Stojanov K. Comparative anatomical study of five species of genus Asparagus in Bulgaria. Trakia J Sci 2013; 11(2): 104-9.

25. Ali M, Bahadur S, Hussain A, Saeed S, Khuram I, Ullah M, et al. Foliar epidermal micromorphology and its taxonomic significance in Polygonatum (Asparagaceae) using scanning electron microscopy. Microsc Res Tech 2020; 83: 1381-90.

26. Riznychuk N, Gniezdilova V. Anatomical structure of Polygonatum Mill. species in the Precarpathian region. Journal Vasyl Stefanyk Precarpath Nat Uni 2020; 7(4): 53-5.

27. Pandey MM, Govindarajan R, Khatoon S, Singh Rawat AK, Mehrotra S. Pharmacognostical Studies of Polygonatum cirrifolium and POlygonatum verticillatum. J Herbs Spices Med Plants 2007; 12: 1(2), 37-48.

28. Kauff F, Rudall PJ, Conran JG. Systematic root anatomy of Asparagales and other monocotyledons. Plant Syst Evol 2000; 223: 13954.

29. Miller R. Polygonatum Mill. In: Flora of Turkey and the East Aegean Islands Volume 8. Davis PH, editor. Edinburgh; Edinburgh University Press; 1984. 
30. Bizim Bitkiler, 2021. 〈https://bizimbitkiler.org.tr/yeni/demos/technical/). (Accessed 22 September 2021).

31. Güner A, Aslan S, Ekim T, Vural M, Babaç MT, editors. Türkiye Bitkileri Listesi (Damarlı Bitkiler). İstanbul: Nezahat Gökyiğit Botanik Bahçesi ve Flora Araştırmaları Derneği Yayını: 2012.

32. Çelebioğlu S, Baytop T. A new reagent for microscopical investigation of plant. Publication of the Institute of Pharmacognosy 1949; 10: 301.

33. Cutler DF, Botha T, Stevenson D, editors. Plant Anatomy an applied approach. Oxford, England: Blackwell Publishing; 2007.

34. Cutter EG. Plant Anatomy Part 2. 2nd ed. Newyork: John Wiley \& Sons Press; 1971.

35. Cutter EG. Plant Anatomy Part 1, 2nd ed. Newyork: Addison-Wesley Press; 1978.

36. Rudall PJ. Anatomy of flowering plants: An introduction to plant structure and development. 3rd ed. Cambridge; Cambridge University Press: 2007.
37. Yentür S. Bitki Anatomisi. İstanbul: İstanbul Üniversitesi Fen Fakültesi Yayınları; 2003.

38. Raycheva T, Stojanov K. Comparative anatomical study of five species of genus Asparagus in Bulgaria. Trakia J Sci 2013; 11 (2): 104-9.

39. Zotz G, Schickenberg N, Albach $D$. The velamen radicum is common among terrestrial monocotyledons. Anal Bot 2017; 120: 62532.

40. Huber H. Die Samenmerkmale und VerwandtschaftsverMltnisse der Liliifloren. München; Mitteilungen der Botanischen Staatssammlung: 1969.

41. Namba T, Komatsu K, Liu YP, Mikage M. Pharmacognostical studies on the Polygonatum plants. I. On the Tibetan crude drug Ra-mnye. Shoyakugaku Zasshi 1991; 45: 99-108.

42. Meng Y, Wang JJ, Nie ZL. Comparative morphology of leaf epidermis in 34 species of Maianthemum (Asparagaceae, Polygonateae) and their systematic significance. Phytotaxa 2016; 275(2): 81-96. 